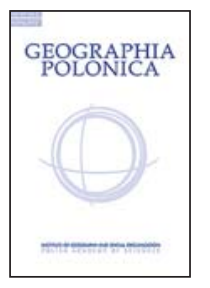

\title{
SOCIALLY INVOLVED AGRICULTURE IN SUSTAINABLE RURAL DEVELOPMENT
}

\author{
Gabriela Czapiewska \\ Institute of Socio-Economic Geography and Tourism \\ Pomeranian University in Słupsk \\ Partyzantów 27, 76-200 Słupsk: Poland \\ e-mail: gabriela.czapiewska@apsl.edu.pl
}

\begin{abstract}
The subject matter being discussed in the article pertains to the idea of socially involved agriculture (social farming). Socially involved agriculture, involving the introduction of social services to already functioning farms, has been developing since the end of the 20th century in rural areas of virtually all of Europe as a new type of innovative activity. Social farming is an idea combining the multifunctionality of farms with care and health services, as well as social entrepreneurship. The aim of the article is an attempt to outline the essence of social farming and emphasise its role in the sustainable rural development in Poland. To this regard, the study combines theoretical considerations with a description of practical solutions in the country. The article presents objectives of social farming, implemented social services, selected initiatives and forms of their support. One of these forms of support in the field of social care and integration in rural areas is a caring farm, offering services based on its resources and infrastructure, enabling, e.g. agrotherapy. Socially involved agriculture is a chance for farmers to provide new services and thus expand and diversify their activities and a multifunctional role in society. Responsible implementation of additional farm functions will contribute to the implementation of a sustainable rural development model.
\end{abstract}

\section{Key words}

social farming $\bullet$ sustainable development $\bullet$ care farming $\bullet$ rural areas

\section{Introduction}

The economic, demographic and social changes currently observed in Poland and Europe affect rural areas in a special way. Sustainability and multifunctionality of rural and agricultural development create benefits both in the sphere of resources, especially those coming from the natural environment, but also in the sphere of management effects and the resulting income of the population (Durand \& Huylenbroeck, 2003; Adamowicz, 2005; Skowroński, 2006; Sandner, 2008; Czapiewska, 2012). Sustainable development of rural areas is characterized by: sustainability (taking care of the inexhaustibility of resources that guarantee its duration in the future), self-sustainability 
(diversification of farm and household sources of income) and integration (combining the internal assets of farms and local communities with external in order to be able to develop local resources) (Nowicki \& Ribbe, 2001; Runowski, 2002; Zabłocki, 2002; Sztumski, 2006; Kronenberg \& Bergier, 2010). The issue of sustainable rural development is gaining importance with the ongoing process of environmental degradation. Due to the important and changing functions of agriculture as one of the sectors of the rural economy, sustainable rural development is not only part of the general current, but more than in other areas of the economy and spatial systems is a way to integrate and achieve economic, social and environmental goals (Constanza, 1991; Piontek, 2002; Woś \& Zegar, 2002; Dacko, 2011; Malik, 2012; Pender, Weber, \& Brown, 2014; Czudec, Miś, \& Zając, 2018).

Multifunctional development is one of the directions indicated in the model of sustainable development - its goal is to improve the living and working conditions of families living in the countryside, as well as to equalize their standard of living in relation to the urban population standard of living (Renting et al., 2008, 2009; Cairol et al., 2009). In this context, in recent years social involvement agriculture ${ }^{1}$ consisting in introducing social services to functioning farms, is increasingly one of the alternatives to classical agriculture (Di lacovo \& O'Connor, 2009; Dessein \& Bock, 2010; Overview of Social Farming..., 2010; Lanfranchi, Giannetto, Abbate, \& Dimitrova, 2015). It develops in rural areas virtually all of Europe as a new type of innovative activity, and its core is to use unique places such as villages and farms to create services for people requiring support. Agricultural activity, apart from the production function, creates unique conditions for supporting education, social integration, therapy, rehabilitation and social services in rural areas. Social

\footnotetext{
1 In Europe, activities known as: rolnictwo opiekuńcze (care farming), rolnictwo dla zdrowia (farming for health), zielona opieka (green care), zielone ćwiczenia (green excercise), terapia rolnicza (agricultural therapy).
}

ideas open the agricultural sector to new opportunities and practical implementation of multifunctionality in agriculture.

The aim of the article is an attempt to outline the essence of social farming and emphasise its role in the sustainable rural development in Poland. To this regard, the study combines theoretical considerations with a description of practical solutions in the country. The article presents objectives of social farming, implemented social services, selected initiatives and forms of their support. The issues are difficult to explore which is why the focus is only on selected aspects - those that provide a guidepost for further reflection and research.

\section{Socially involved agriculture idea - definition, goals, reasons for development in Europe}

Socially involved agriculture is an idea combining the multifunctionality of farms, understood as the possibility of satisfying not only production and market needs, but also nonagricultural (environmental, cultural, economic and social) needs with care and health services, as well as social entrepreneurship. According to the European Economic and Social Committee, social farming is an innovative approach combining two concepts: multifunctional agriculture and social services and/or health care at the local level. Social farming provides an opportunity to improve the well-being of individuals and collective integration of people at risk of social exclusion (Opinia Europejskiego..., 2013).

The concept of social farming - although it sounds innovative - has in fact a long tradition reaching back to local self-help networks in the villages that were created before the era of social security systems. In the second half of the nineteenth century, farms and dedicated institutions located in rural or peripheral areas were used to provide care for people with intellectual disabilities, while observing the salutary impact of nature on those staying there (Kamiński, 2014). Already in the Middle Ages, prisons, hospitals and monasteries 
used the natural environment for therapeutic purposes (Elings, 2012).

In today's form, the movement began to revive already in the 70s of the twentieth century in several countries in parallel: in the Netherlands, Italy, Germany and Ireland. It is worth noting that the Netherlands is widely regarded as a pioneer in the field of social farming and care homes. The beginnings of their development in this country date back to the 60s and are associated with two tendencies - the search for optional forms of health care and the search for alternative sources of income for farmers.

The reasons for the development of social farming in Europe was different depending on the country. After closure of institutional facilities in Italy cooperative services providing care services began. In Ireland and Netherlands underlying were religious movements and religious communities that organized their own farms. In Germany (next to religious background), social farming developed on the basis of sheltered workshops (Di lacovo \& O'Connor, 2009; Rozwój rolnictwa..., 2017).

In the opinion of J. Dessein and B. Bock (2010), there are three approaches / discourses on social farming that are used to define the concept, perception of the idea, its implementation and regulation in different countries. These are: multifunctional agriculture, public health and social inclusion. Generally speaking, socially involved agriculture can be defined as a set of actions using agricultural resources to generate welfare and social services provided in rural or suburban areas. Such activities include: rehabilitation, therapy, resocialization, care for the elderly and dependents, sheltered work, lifelong education and other activities that contribute to social inclusion (Hine, Peacock, \& Pretty, 2008; Di lacovo \& O’Connor, 2009; Rozwój rolnictwa..., 2017). Therefore, social farming includes the involvement of resources from active farms and the agricultural landscape, as well as daily farm activities to improve physical and mental condition (Haubenhofer, Elings, Hassing, \& Hine, 2010; Leck, Upton,
\& Evans, 2015). Projects undertaken on agricultural holdings can be basically divided into two groups:

- actions using plant and animal resources (e.g. animal feeding, milking, dairy production, horse riding, cleaning of utility rooms);

- activities based on local tradition and culture (including handicrafts, processing, seasonal farm work).

Currently, social farming in Europe is in various stages of development. In the opinion of Di lacovo and O'Connor (2009), four stages of its development can be indicated:

1. Pioneering form - characterised by voluntary action rooted in a strong motivation. Private farms undertake their own projects and farmers enter the system because of their own commitment (e.g. Slovenia, Poland).

2. Professionalization of social farming. The interest comes mainly from agriculture and there are local initiatives, both private and public. Social economy is supported by funds from the agricultural and rural development domain (e.g. Flanders region in Belgium).

3. Social farming as a recognised system in social/health care. Public institutions related to social welfare or health recognise social farming as relevant applying to both private and public structures. Social farms are often developed into professionally-based, care-oriented farms that are part of the health care sector (e.g. Germany, Ireland).

4. Social farming as an inclusive model: In this stage there is a large number of initiatives, strongly embedded at grassroots level and in the wider society. They have organised themselves into regional and national networks. There is involvement from both the agricultural and social care/health sectors (e.g. Netherlands, Italy, France).

Models of social farming implementation vary depending on the country, culture, motivating factors, historical experience or the possibility of obtaining support or establishing cooperation as part of systemic solutions in the health and social assistance sector. The experience of other countries shows that 
the concept of social farming is a multifunctional value and brings many different benefits (Hassink \& Van Dijk, 2006; Sempik, Hine, \& Wilcox, 2010). Di lacovo and O'Connor (2009) are of the opinion that social farming can be an inspiring example for the sustainable development of multifunctional agriculture, as it gives the opportunity for farm owners to engage in other sectors (such as education, health) and building new networks and relationships that can be helpful in promoting production.

Due to the diverse goals of farms undertaking a social mission, they can be divided into: caring (providing short and long-term care), therapeutic, social and educational. Therefore, farms have the potential to provide educational services, such as afterschool activities or activities for children with special educational needs (educational farms). At the same time, they are a good place to use therapy based on communing with nature (silvotherapy) in supporting and treating people with mental disorders. They can also act as a refuge for older people often struggling with the problem of limited independence and diseases, including dementia. Through diverse classes and activities, people

Table 1. Typology of social farms in Europe

\begin{tabular}{|c|c|}
\hline Classification criteria & Farm types \\
\hline Links with the social assistance system & $\begin{array}{l}\text { - institutional } \\
\text { - based on family activities }\end{array}$ \\
\hline Leading entities & $\begin{array}{l}\text { - family farm } \\
\text { - institution (public or private sector) } \\
\text { - enterprise / business activity } \\
\text { - cooperative } \\
\text { - association }\end{array}$ \\
\hline Agricultural activity profile & $\begin{array}{l}\text { - plant production (crops, gardening) } \\
\text { - animal production } \\
\text { - food processing } \\
\text { - fishing } \\
\text { - organic farm, etc. }\end{array}$ \\
\hline Business profile & $\begin{array}{l}\text { - care services } \\
\text { - therapy } \\
\text { - re-education, resocialisation } \\
\text { - social inclusion } \\
\text { - vocational integration and activation, preparation for work } \\
\text { - teaching activities } \\
\text { - tourist services }\end{array}$ \\
\hline Target groups & $\begin{array}{l}\text { - people distant from the labor market (permanently unemployed) } \\
\text { - people burned out professionally } \\
\text { - people fighting addiction (from alcohol, drugs) } \\
\text { - people who have been imprisoned } \\
\text { - people with mental disorders (including dementia) - older people } \\
\text { (requiring care or independent, seeking company) } \\
\text { - children and young people as part of educational projects, } \\
\text { - difficult youth as part of socio-therapeutic or educational therapy, } \\
\text { - physically and / or intellectually disabled people }\end{array}$ \\
\hline Duration of care & $\begin{array}{l}\text { - hourly and daily stays (day support facility model) } \\
\text { - short-term (respite) and long-term (24-hour care model) stays }\end{array}$ \\
\hline Location of forms of social farming & $\begin{array}{l}\text { - rural areas } \\
\text { - suburban areas } \\
\text { - cities }\end{array}$ \\
\hline
\end{tabular}

Source: elaboration based on Rozwój rolnictwa... (2017: 8-9). 
in difficult life situations with special needs are activated and stimulated to act.

In recent years, an increasing number of entities interested in rural areas are paying attention to social farming. This interest is due to an increasingly better understanding of the role that agriculture and rural resources can play in improving the social, physical and mental condition of the population. At the same time, social farming is a chance for farmers to provide new services and thus expand and diversify their activities as well as multifunctional role in society. Such integration of agricultural and social measures can also provide farmers with additional sources of income and improve the image of agriculture in the eyes of the public (Social Farming, 2014). The use of new agricultural functions, such as social farming, will contribute to the development of entrepreneurship in rural areas in innovative directions (Kamiński, 2014).

Socially involved agriculture, in particular care farms, plays a very important role in the context of the challenges of an aging population, resulting in reduced labor resources and an increase in the number of people needing support (disabled, threatened with exclusion, seniors). It is estimated that by 2030, in Poland, the number of people over 75 years of age requiring care in nursing homes will increase by nearly 21,000 , and the demand will be a half bigger than the quantity of planned increase of places in nursing homes (Szweda-Lewandowska, 2008). It is also worth adding that according to Statistics Poland forecasts, in 2030 , a total of $53.3 \%$ of single-person households will be maintained by people aged at least 65 , including $17.3 \%$ by people aged 80 and over (Statistics Poland, 2011).

Social farming is an initiative undertaken in a rural environment and combines not only the desire to achieve social goals, but also the desire to diversify agricultural activities, activate the population in rural areas and use human capital - undeveloped resources, potential and skills of rural residents (Rozwój rolnictwa ..., 2017).

The idea of socially involved agriculture has many strengths. Being in nature, participating in farming activities and being

Table 2. Potential benefits of social farming

\begin{tabular}{|c|c|}
\hline $\begin{array}{l}\text { Dimension } \\
\text { of benefits }\end{array}$ & Specification \\
\hline Economic & $\begin{array}{l}\text { - additional jobs in rural areas, } \\
\text { - source of income for agriculture-related families, } \\
\text { - activation of the elderly, the disabled persons and distant from the labor market, } \\
\text { the provision of care services, } \\
\text { - additional revenues to local budgets, } \\
\text { - counteraction rural depopulation, } \\
\text { - positive impact on the maintenance of public infrastructure (schools, offices, roads, etc.) } \\
\text { in sparsely populated areas }\end{array}$ \\
\hline Social & $\begin{array}{l}\text { - better well-being and health of care beneficiaries, } \\
\text { - increased awareness of the local community, } \\
\text { - creating facilities for health care and social assistance based on the resources of local } \\
\text { - bommunities, }\end{array}$ \\
\hline Technology & $\begin{array}{l}\text { - the possibility to create a new function for the farm without the need to invest in expensive } \\
\text { technologies to improve agricultural production, } \\
\text { - reduction of negative impact on the natural environment }\end{array}$ \\
\hline For agriculture & $\begin{array}{l}\text { - the possibility of maintaining a multi-functional farm, } \\
\text { - an opportunity to promote a new image of agriculture among representatives of all } \\
\text { generations }\end{array}$ \\
\hline
\end{tabular}

Source: own elaboration based on Rozwój rolnictwa... (2017: 10), Stępnik (2018: 12). 
aware of being a useful member of a group of people are the factors that play a huge role in ensuring well-being and improving health regardless of age (Gospodarstwa opiekuńcze..., 2017). Contact with the authentic rhythm of the farm, its plants and livestock, participation in the food production cycle have a scientifically proven beneficial effect on human emotional and mental development (Webb, 2012; Tournier \& Postal, 2014; Leck et al., 2015).

Agriculture with a social mission is at the interface of several economic sectors, such as the agri-food sector, tourism, healthcare, education and the labor market. Social agriculture is an idea combining a number of different policies, including Community agriculture and rural policies, social policy and strategies for preventing exclusion, issues in the field of health protection, education and human rights. The opportunities arising from the diversification of agricultural activities are not only additional sources of income or satisfaction from sharing your resources (part of the popular idea of sharing economy), but also undoubtedly a great opportunity for farmers and their families, the opportunity for wider professional and personal development as well as performing multidimensional roles for the local community. Therefore, socially involved agriculture is a developing direction, aiming to provide a wide group of recipients health, social and educational benefits resulting from agricultural activity.

\section{Care farms as an example of social innovation from the Polish perspective}

A special type of social farming is a caring farm - form of farming that combines farming with caring for people that need support. This is a new concept, but it has been successfully implemented in many European countries and more often in Poland (Bucholz, 2014; Manintveld, 2014; Toby, 2014). The most important feature of these farms is the use of the farm's potential to carry out therapeutic, caring and integrating activities. Therefore, in the process of creation and functioning of such institutions, farmers or members of the household farms must be involved (Ordyczyński, 2004). Services are provided based on the farm infrastructure and in connection with the agricultural activity carried out. The facility where the caring farm is organized should have farm animals or agricultural crops, which can be used in agrotherapy. It includes intentional improvement (physically and mentally) influences, implemented using the landscape and rural infrastructure (or farm), through participation in field work, assistance in grooming animals, assistance in plant cultivation, eco-production, processing of agricultural products or participation in activities in farm (traditional arts and crafts, creativity and folk rituals, preparation of regional dishes, etc.).

The main reasons for the development of care farms in rural areas are: (Kamiński, 2014):

- seeking new sources of income for farms (the need to diversify agricultural incomes),

- development of entrepreneurship increase in the popularity of social farming,

- the need for sustainable rural development,

- hidden unemployment - creating new jobs,

- demographic changes - aging of the population,

- singularization of old age,

- changing demand for care services,

- the need to change the organization of care for the elderly.

Care farms are an example of social innovation because they combine the achievement of economic effects and significant social benefits - a combination of both the economic (agriculture) and social policy spheres (care). The economic dimension of care farms functioning should not only be considered from the potential reduction of care costs incurred by local governments and families of people in need point of view. It is a chance for survival and development 
for small family farms. Therefore, care farms should be seen not only as an instrument of social policy, but also as part of rural development policy. Thus, it can be concluded that the idea of care farms development in Poland is a response to market needs and the social and economic developmental threats facing rural areas (Stępnik, 2018).

The caring farm allows any free labor resources of the villages to be used for a just cause, which is the need to provide care for the elderly living in less populated areas. The village is a source of knowledge and experience in caring for the elderly with concurrent deficiencies in infrastructure in the form of institutional and stationary forms of care. In conjunction with human internal motivation to do something socially right, and financial motivation associated with increasing revenues from outside agriculture, the idea of care farms seems to be a win-win solution for all stakeholders.

From the point of view of current and future seniors, not only life expectancy, but also its quality is important. The contemporary older generation has an increasing health awareness and growing expectations of their own old age, the determinants of which are, apart from maintaining fitness are also independence, independence and both professional and social activity (Kmita-Dziasek, 2015). Therefore, the aging of the population increases the demand for modern rehabilitation, therapeutic, integration and care services. Numerous scientific studies indicate that rural areas and agriculture create great opportunities for the development of this type of services. Contact with nature, staying on a farm and participating in his daily life have a beneficial effect on human health and fitness.

As part of social functions, a farm may fulfil the tasks of: re-education and resocialization (e.g. people leaving penitentiary facilities), therapy (restoring health to sick people through various means and treatments), integration on the labour market (professional activation), pedagogical activities, care services (satisfying daily life needs, providing hygienic care, physician-ordered care, ensuring contact with the environment), social inclusion (the process of involving individuals, groups or social categories in the functioning of a wider society).

Care farms can operate on the basis of three organizational forms: day residence, family social home, care facility (as part of business operations). Leading a caring farm is not only the need to provide work for people staying there, but also diverse activities, transport, accommodation, meals and professional care appropriate to the needs and profile of the farm. These responsibilities require different competences, appropriate roles and management skills.

Care farms offer a variety of occupational therapies aimed at: activating individuals for a quick recovery and improvement of wellbeing, enabling participation in social life, improving functional fitness in the field of basic and complex activities of everyday life, help in solving life problems, promoting a healthy lifestyle or developing passions and interests.

Current legal conditions limit the possibilities of combining agricultural activity with the provision of care services. Legal forms enabling households to apply for welfare, public funding may be: economic activities, the creation of non-governmental organizations (associations, foundations) or social economy entities (social cooperatives, Center for Social Initiatives) the implementation of services in the form of family care homes, family children's homes or foster families. Running a caring farm as part of a business activity or as part of the statutory activity of a nongovernmental organization gives you the opportunity to take advantage of readymade patterns of action and requirements that are set for social welfare system units. In the era of growing care needs for the growing number of elderly and dependent people in aging societies, there are still few places in rural areas offering such profiled services. 


\section{Social agriculture as a new function of rural areas in Poland - development perspectives, examples of implemented initiatives}

Social farming is an emerging topic for different stakeholders in Poland: farmers, farmers' organisations, service-users of social farms and their organisations, providers of social and health care services, other stakeholders in social and health care and local, regional and national authorities. Currently, more and more attention is paid to the social aspects of agriculture, but also new solutions, ways to involve the local community, and to solve many examples of social problems in rural areas are being looked for. It is also optimistic that in Poland the directions of development of social farming are gradually implemented as part of many adopted and implemented transnational, national and regional strategies, where not only activities aimed at activating the community or supporting innovation in rural areas are planned, but also aimed at creating a framework and system solutions to increase access to care services in the villages ${ }^{2}$.

Based on the experience of the Netherlands, practical implementation of the idea of social farming in Polish reality began (Bucholz, 2014; Manintveld, 2014). The first pilot project "Green care - care farms in the Kuyavian-Pomeranian Voivodeship" was implemented from September 2016 to June

\footnotetext{
2 Strategic documents containing provisions regarding the development of social agriculture: Program Rozwoju Obszarów Wiejskich 2014-2020, Rządowy Program na rzecz Aktywności Społecznej Osób Starszych na lata 2014-2020 (Program ASOS), Program Solidarność pokoleń. Działania dla zwiększenia aktywności zawodowej osób w wieku 50+, Założenia Długofalowej Polityki Senioralnej w Polsce na lata 20142020, Program Działań Ministerstwa Rolnictwa i Rozwoju Wsi na lata 2015-2019, Strategia Zrównoważonego Rozwoju Wsi, Rolnictwa i Rybactwa (SZRWRiR) na lata 2012-2020, Strategia na Rzecz Odpowiedzialnego Rozwoju, Krajowy Program Rozwoju Ekonomii Społecznej, Krajowa Sieć Obszarów Wiejskich (KSOW), Regionalne Programy Operacyjne 2014-2020.
}

2018 by the Kuyavian-Pomeranian Agricultural Advisory Center in Minikowo in partnership with the Local Action Group "Bory Tucholskie"3. The aim of the project was to provide day care for 225 disabled people from rural areas in 15 farms (in Brodnica, Mogilno, Świecie, Tuchola and Wąbrzeźno poviats) and to raise the competence of 30 farmers in the field of care services. During the project 246 people in need benefited from day care provided in the form of care homes $68.7 \%$ women and $31.3 \%$ men. It is worth adding that $53 \%$ of project participants were over 70 years old, which clearly indicates that the vast majority of pupils needed support because of their age.

Another project "Care in the yard - care farms in the Kuyavian-Pomeranian Voivodeship" is a continuation of the above-named. The main goal of the project, whose implementation began in September 2018, is to increase the availability of caring and activating services for another 225 disable people in the form of day stay by creating and developing an offer of care farms providing 75 places in rural areas in the Kuyavian-Pomeranian Voivodeship (in Brodnica, Golub-Dobrzyń, Lipno, Rypin, Sępólno-Krajeńskie, Świecie, Tuchola, Wąbrzeźno, Włocławek and Żnin poviats) and raising competences in the care for 25 farmers by August 2020.

Thanks to the projects implemented by the Kuyavian-Pomeranian Agricultural Advisory Center, the idea of care farms has become the subject of state policy. Activities for the creation of this type of farms have been included in the inter-ministerial project '(Un) independent', which is part of the implementation of the Strategy for Responsible Development (SRD). This project assumes that by 2023500 care homes will be created in Poland, in which at least 500 jobs will be created and 2,500 places for people in need of support.

\footnotetext{
3 Project implemented as part of the Regional Operational Program of the Kuyavian-Pomeranian Voivodeship for 2014-2020; http://www.opieka.kpodr. $\mathrm{pl} / \mathrm{pl} /$ front/ [12 July 2019].
} 
Activity undertaken by the Agricultural Advisory Center Branch in Kraków for the development of social farming in Poland is CARE-T-FARMS. It was program cofinanced under the Erasmus+ Strategic Partnerships for vocational education and training (KA202). The project was implemented from $01 / 11 / 2017$ to $31 / 10 / 2019$ in cooperation with organizations from Belgium, Spain, Poland, Turkey and Italy. The aim of the project was to create an innovative training course using the interactive e-learning platform with open access to educational resources. In the preparatory phase, project partners examined best practices in social farming in Poland, Italy, Turkey and Spain. Combining examples with theoretical knowledge about the optimal ways of running a social farm has become the basis for developing three appropriate training modules, each of which will be directed to a different target group:

- first module "Care Farm Tutor" is addressed to farmers, farm workers, high school students and pupils,

- second module named "Care Farm Manager" is dedicated to farmers who have experience in teaching and receiving people on their farms,

- third module "Care Farm Social / Health Educator" is intended for social workers, psychologists and psychiatrists who have experience in therapeutic assistance. This module will be a source of specialist knowledge on the planning of social and care activities on a farm as part of, among others non-clinical treatment. Having access to this type of training, an increase of interest in social (caring) agriculture and its popularization is expected ${ }^{4}$.

Thinking about the target group of social farming, which are children and youth, the Agricultural Advisory Center Branch in Kraków has established a National Network of Educational Farms ${ }^{5}$. It brings together farms with different business profiles, open

\footnotetext{
4 http://www.care-t-farms.eu/index.php/pl/ [28 May 2019].

5 www.zagrodaedukcyjna.pl [19 July 2019].
}

to receive school groups and guests for educational, tourist and recreational purposes (Czapiewska, 2018). On the basis of farms performing social functions, a network of friendly places may be created in Poland where elderly or people experiencing illnesses, disabilities and loneliness would find support. The main assumption of the GROWID project "Caring farms in rural development in the face of demographic challenges" 6 is creation tools that will lead to the implementation of this vision in Poland. The main purpose of the GROWID project, implemented from January 2019 to December 2021, is developing a caring farm model and prepare an implementation system in the form of a caring farm development strategy. In the first stage of the project, research tasks will be carried out, the results of which will become the basis for the care farm model. The second stage consists of work related to the preparation for implementation of the model (including the development of necessary legal regulations).

Activities implemented by agricultural advisory centres are also supplemented by the activities of other governmental and local institutions with the involvement of the Ministry of Agriculture and Rural Development. An example is the pilot program of comprehensive care for the elderly from rural areas "Active and healthy senior farmer" implemented by the Agricultural Social Insurance Fund. 'The program was created in response to the need to search for innovative solutions in the area of organization and provision

\footnotetext{
6 The GROWID project "Caring farms in rural development in the face of demographic challenges" is financed by the Strategic program of scientific research and development works "Social and economic development of Poland in the conditions of globalizing markets" GOSPOSTRATEG, and its partners are: Ministry of Agriculture and Rural Development, Jagiellonian University in Kraków, University of Agriculture Kołłataja in Kraków; https:// www.cdr.gov.pl/projekty-i-wspolpraca/2898-growidgospodarstwa-opiekuncze-w-rozwoju-obszarow-wiejskich-wobec-wyzwan-demograficznych [2 June 2019\}; https://growid.pl [3 June 2019].

7 http://www.minrol.gov.pl/Ministerstwo/BiuroPrasowe/Informacje-Prasowe/W-trosce-o-seniorow-naobszarach-wiejskich [14 July 2019].
} 
of care, rehabilitation and preventive health services among farmers, taking into account the risk of accidents in agriculture, illnesses typical for elderly people and the specificity of agricultural work. The project implemented from 2018 to 2020 based on the housing and rehabilitation base of KRUS and other care and treatment centers; is addressed to persons subject to farmers' social insurance.

Social farming in Poland may have a wide impact on many aspects of agriculture and its links with society, arising from:

- the benefits for 'service-users', in terms of empowerment, quality of life, social inclusion, education, employment and therapy;

- innovation: in agriculture, social welfare, health care and education;

- new sustainable links between agriculture, social and health care sectors, education and society.

\section{Summary}

Social farming is an idea which is reflected in practical activity consisting in expanding the catalog of agricultural activities with social services (e.g. educational services, care services, therapeutic services, and social inclusion services).

Socially involved agriculture meets many of the problems of modern civilization by responding to social challenges implied by social stratification, aging of societies, development of civilization diseases, including mental disorders and addictions, increase of pathologies and social dysfunctions and problems of the labor market.

New challenges affect the development of entrepreneurial attitudes of farmers in the direction of increasing their social responsibility, including the implementation of proecological solutions. In its assumptions, social farming returns to the traditional structures of a multi-generational family and natural self-help networks typical of rural local communities.

In global terms, the development of social farming can contribute to an increase in the number of innovative initiatives, both in the agricultural sector as well as in the health care, education and social sector. On a national scale, however, it will require the creation of necessary facilities for rural residents, agricultural advisory services, local governments, NGOs and other entities that will be actively involved in this process. In Polish conditions, it is still more of a social innovation than the widely implemented practice.

The possibility of conducting additional activity in many farms will improve the economic situation of entire local communities. In addition, the number and level of social services offered in rural areas will also increase. Socially involved agriculture will contribute to the promotion of healthy and proactive attitudes among the rural population. Conducting social activities, whose recipients can be not only local residents, but also people from nearby cities, will strengthen links between the village and the city. Systematic implementation of the idea of social farming in practice will also help to increase the role played by farmers in their local communities and to shape the positive image of the entire agricultural sector in Poland.

With the increasing number of elderly and in need of support, the demand for care services also increases. It is therefore necessary to create solutions that on one hand will allow increasing the availability of high-quality social services in rural areas, and on the other hand will be economically justified in specific, rural conditions.

Actions taken by agricultural advisory centres have proven that caring farms are a solution that works in Polish conditions. The 'Green Care' and 'Care in the Farm' projects are an example of a good, innovative solution in the sphere of senior policy. In turn, experience related to the functioning of the Educational Farm Networks indicates an important role that farms can have in the education process.

The creation of care farms will improve the quality of life in rural areas. They will contribute to solving the problem of inequalities in access to social services, which particularly 
affect the inhabitants of smaller towns. This will be important not only for people who require direct support, but also for caregivers of dependent people, who often have to give up their careers for this reason. Responsible implementation of additional farm functions also contributes to the implementation of a sustainable rural development model. According to experts, a further increase in popularity of initiatives derived from the economics of sharing or collaboration, such as socially sustainable agriculture, may also be supported by dynamic technology development and the emergence of new Internet portals.

Editors' note:

Unless otherwise stated, the sources of tables are the authors', on the basis of their own research.

\section{References}

Adamowicz, M. (2005). Zrównoważony i wielofunkcyjny rozwój rolnictwa a agronomia. Annales Universitatis Mariae Curie-Skłodowska. Sectio E. Agricultura, 60, 71-91.

Bucholz, M. (2014). Bory Tucholskie dla seniora [in:] Gospodarstwa opiekuńcze w Borach Tucholskich a doświadczenia holenderskie. Minikowo: Kujawsko-Pomorski Ośrodek Doradztwa Rolniczego.

Cairol, D., Coudel, E., Knickel, K., Caron, P., Kröger, M. (2009). Multifunctionality of agriculture and rural areas as reflected in policies: the importance and relevance of the territorial view. Journal of Environmental Policy \& Planning, 11(4), 269-289. https://doi.org/10.1080/15239080903033846

Constanza, R. (1991). The ecological economics of sustainability [in:] R. Goodland, H. Daly, S. El Serafy, B. von Droste (eds.) Environmentally sustainable economic development (pp. 83-90). Paris: Building on Brundtland UNESCO.

Czapiewska, G. (2012). Przemiany struktury funkcjonalno-przestrzennej Pomorza w ujęciu wielofunkcyjnego i zrównoważonego rozwoju. Acta Scientiarum Polonorum Administratio Locorum, 11(2), 49-63.

Czapiewska, G. (2018). Innowacyjność i aktywność społeczna w rozwoju obszarów wiejskich Pomorza - przykład zagród edukacyjnych. Acta Universitatis Lodziensis. Folia Geographica Socio-Oeconomica, 31, 39-58. https://doi.org/10.18778/1508-1117.31.03

Czudec, A., Miś, T., Zając, D. (2018). Zrównoważony rozwój obszarów wiejskich w wymiarze regionalnym. Poznań: Wydawnictwo Naukowe Bogucki.

Dacko, M. (2011). Koncepcja zrównoważonego rozwoju w naukach ekonomicznych - inspiracje, ewolucja, perspektywy [in.] A. Bałtromiuk i M. Kłodziński (eds.) Natura 2000 jako czynnik zrównoważonego rozwoju obszarów wiejskich regionu Zielonych Płuc Polski (pp. 19-48). Warszawa: Instytut Rozwoju Wsi i Rolnictwa Polska Akademia Nauk.

Dessein, J., Bock, B. (2010). The economics of green care in agriculture. Loughborough: Loughborough University Press.

Di lacovo, F., O'Connor, D. (ed.) (2009). Supporting policies for social farming in Europe. Progressing multifunctionality in responsive rural areas, SoFar project: Supporting EU agricultural policies. Italy: Arsia, Florenz.

Durand, G., Van Huylenbroeck, G. (2003). Multifunctionality and rural development: General framework [in:] G. van Huylenbroeck i G. Durand (eds.) Multifunctional agriculture. A new paradigm for European agriculture and rural development (pp. 1-16). Hampshire: Ashgate Publishing Company.

Elings, M. (2012). Effect of care farms. Scientific research on the benefits of care farms for clients. Wageningen: Plant Research International.

Gospodarstwa opiekuńcze. Budowanie sieci współpracy. (2017). Kraków: Centrum Doradztwa Rolniczego w Brwinowie Oddział w Krakowie. Retrieved from 
http://cdr112.ekei.pl/gospodarstwaopiekuncze/images/publikacje/broszura/gospodarstwa_opiekuncze.pdf [10 May 2019].

Hassink, J., Van Dijk, M. (2006). Farming for health across Europe. Comparison between countries, and recommendations for a research and policy agenda [in:] J. Hassink, M. Van Dijk (eds.) Farming for health (pp. 347-357). Wageningen: Wageningen University and Research Centre. https://doi.org/10.1007/1-4020-4541-722

Haubenhofer, D.K, Elings, M, Hassing, J., Hine, R.E. (2010). The development of green care in Western European countries. EXPLORE, 6(2),106-111. https://doi.org/10.1016/j.explore.2009.12.002

Hine, R., Peacock, J., Pretty, J. (2008). Care farming in the UK: Evidence and opportunities. Report for the National Care Farming Initiative. Essex: University of Essex.

Kamiński, R. (2014). Gospodarstwa opiekuńcze jako alternatywna ścieżka rozwoju gospodarstw agroturystycznych. Minkowo: Kujawsko-Pomorski Ośrodek Doradztwa Rolniczego.

Kmita-Dziasek, E. (2015). Wprowadzenie do zagadnień edukacji w gospodarstwie rolnym. Kraków: Centrum Doradztwa Rolniczego w Brwinowie Oddział w Krakowie.

Lanfranchi, M., Giannetto, C., Abbate, T., Dimitrova, V. (2015). Agriculture and the social farm: expression of the multifunctional model of agriculture as a solution to the economic crisis in rural areas. Bulgarian Journal of Agricultural Science, 21, 711-718.

Leck, CH., Upton, D., Evans, N. (2015). Growing well-beings: The positive experience of care farms. British Journal of Health Psychology, 20, 745-762. https://doi.org/10.1111/bjhp.12138

Kronenberg, J., Bergier, T. (2010). Wyzwania zrównoważonego rozwoju w Polsce. Kraków: Wydawnictwo Fundacja Sendzimira.

Malik,K. (2012). The effectiveness and efficiency of regional development policy [in:] G. Hofbauer, H. Haensel (eds.) Challenges, Research and Perspectives - Herausforderungen, Forschung und Perspectiven. European Research and Working Group (pp. 287-300). Berlin: Uni-edition GmbH.

Manintveld, K. (2014). Gospodarstwa opiekuńcze w Holandii [in:] Gospodarstwa opiekuńcze w Borach Tucholskich a doświadczenia holenderskie. Minikowo: Kujawsko- Pomorski Ośrodek Doradztwa Rolniczego.

Nowicki, M., Ribbe, L. (2001). Problemy ekorozwoju Polski. Warszawa: Agencja Reklamowo-Wydawnicza Grzegorczyk.

Opinia Europejskiego Komitetu Ekonomiczno-Społecznego w sprawie: "Rolnictwo społeczne: zielone usługi terapeutyczno-opiekuńcze oraz polityka społeczna i zdrowotna", Dziennik Urzędowy Unii Europejskiej 5.2.2013 (2013/C 44/07).

Overview of Social Farming and Rural Development Policy and Selected EU Member States. NRN Joint Thematic Initiative on Social Farming. (2010). European Communities.

Ordyczyński, M. (2004). Rodzinne gospodarstwa opiekuńcze [in:] A. Futymski, K. Leśniak, B. Lof, K. Manintveld (eds.) Nowe podejście do rozwoju obszarów wiejskich w Polsce. Doświadczenia projektu"Budowanie Instytucji na Rzecz Rozwoju Wsi w Pilotażowych Regionach Polski - IBRD" (p.30). Leżajsk: Leżajskie Stowarzyszenie Rozwoju.

Pender, J.L., Weber, J.G., Brown, J.P. (2014). Sustainable rural development and wealth creation: Five observations based on emerging energy opportunities. Economic Development Quarterly, 28(1), 73-86. https://doi.org/10.1177/0891242413513327

Piontek, B. (2002). Koncepcja rozwoju zrównoważonego i trwałego Polski. Warszawa: Wydawnictwo Naukowe PWN.

Renting, H., Rossing, W.A.H., Grootb, J.C.J., Van Der Ploega, J.D., Laurentc, C., Perraudd, D., Stobbelaare, D.J., Van Ittersumf, M.K. (2009). Exploring multifunctional agriculture. A review of conceptual approaches and prospects for an integrative transitional framework. Journal of Environmental Management, 90(2),112-123. https://doi.org/10.1016/j.jenvman.2008.11.014 
Renting, H., Oostindie, H., Laurent, C., Brunori, G., Barjolle, D., Jervell, A.M., Granberg, L., Heinonen, M. (2008). Multifunctionality of agricultural activities, changing rural identities and new institutional arrangements. International Journal of Agricultural Resources, Governance and Ecology, 79(4), 361-385. https://doi.org/10.1504/ijarge.2008.020083

Rozporzadzenie Ministra Pracy i Polityki Społecznej z 31.05.2012 r. w sprawie rodzinnych domów pomocy (Dz.U. 2012 poz. 719).

Rozwój rolnictwa społecznego w Europie na przykładzie gospodarstw opiekuńczych w wybranych krajach europejskich. (2017). Raport PCG Polska na zlecenie Ministerstwa Rolnictwa i Rozwoju Wsi. Warszawa.

Runowski, H. (2002). Rozwój zrównoważony rolnictwa i gospodarstw rolniczych. Wieś i rolnictwo - perspektywy rozwoju. Warszawa: Instytut Ekonomiki Rolnictwa i Gospodarki Żywnościowej, Instytut Rozwoju Wsi i Rolnictwa Polska Akademia Nauk, Szkoła Główna Handlowa.

Sandner, J. (2008). Zrównoważony rozwój szansa dla ludzkości. Warszawa: Wydawnictwo Uniwersytetu Kardynała Stefana Wyszyńskiego.

Sempik, J., Hine, R., Wilcox, D. (eds.) (2010). Green care: A conceptual framework, a report of the working group on the health benefits of green care. Loughborough: Centre for Child and Family Research. Loughborough University.

Skowroński, A. (2006). Zrównoważony rozwój perspektywą dalszego postępu cywilizacyjnego. Problemy Ekorozwoju, 2, 47-57.

Social Farming. (2014). European Network for Rural Development. https://enrd.ec.europa.eu/enrd-static/themes/social-aspects/social-farming/en/social-farming_en [11 June 2019].

Statistics Poland. (2011). Powszechny Spis Rolny 2010 - Raport z wyników. Warszawa: Główny Urząd Statystyczny.

Stępnik, K. (2018). Gospodarstwa opiekuńcze - oczekiwane korzyści społeczne i ekonomiczne [in.] J. Lesiewicz (ed.) Rozwój usług opiekuńczych na terenach wiejskich. Minikowo: Kujawsko-Pomorski Ośrodek Doradztwa Rolniczego w Minikowie.

Sztumski, W. (2006). Idea zrównoważonego rozwoju, a możliwości jej urzeczywistnienia. Problemy Ekorozwoju, 1(2), 73-76.

Szweda-Lewandowska, Z. (2008). Prognoza zapotrzebowania na miejsca w domach pomocy społecznej dla osób w wieku 75 lat i więcej [in:] J.T. Kowalewski i P. Szukalski (eds.) Starzenie się ludności Polski - między demografiq a gerontologiq społecznq (pp. 125-151). Łódź: Wydawnictwo Uniwersytetu Łódzkiego.

Toby, A. (2014). Modele gospodarstw opiekuńczych według grup docelowych [in:] Gospodarstwa opiekuńcze w Borach Tucholskich a doświadczenia holenderskie. Minikowo: Kujawsko-Pomorski Ośrodek Doradztwa Rolniczego.

Tournier, I., Postal, V. (2014). Proposition d’un modèle intégratif concernant les bénéfices psychologiques du jardinage chez les personnes âgées. Ger Psychol Neuropsychiatr Vieil, 12(4), 424-431.

Webb, L. (2012). The recovery model and complex health needs: What health psychology can learn from mental health and substance misuse service provision. Journal of Health Psychology, 17(5), 731-741. https://doi.org/10.1177/1359105311425276.

Woś, A., Zegar, S. (2002). Rolnictwo społecznie zrównoważone. Warszawa: Instytut Ekonomiki Rolnictwa i Gospodarki Żywnościowej.

Zabłocki, G. (2002). Rozwój zrównoważony - idee, efekty, kontrowersje. Toruń: Wydawnictwo Uniwersytetu Mikołaja Kopernika. 